\title{
Data report: IODP Site U1387: the revised splice between Sections U1387B-18X-3 and U1387C-8R-3 (>171.6 mcd) ${ }^{1}$
}

\author{
Antje H.L. Voelker, ${ }^{2,3}$ Francisco J. Jimenez-Espejo, ${ }^{4,5}$ André Bahr, ${ }^{6}$ Andreia Rebotim, ${ }^{2,3,7}$ \\ Catarina Cavaleiro, 2, 3, 7 Emília Salgueiro, ${ }^{2,3}$ and Ursula Röhl ${ }^{7}$
}

\section{Chapter contents}

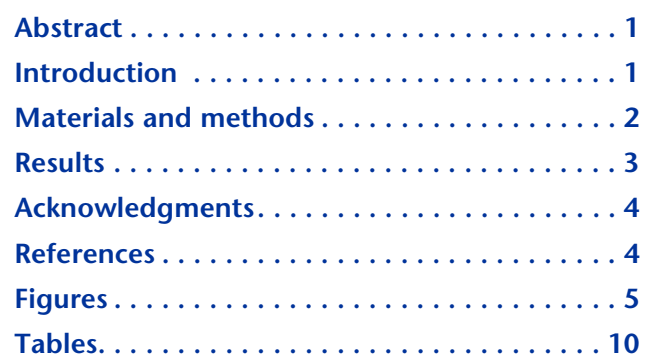

1Voelker, A.H.L., Jimenez-Espejo, F.J., Bahr, A., Rebotim, A., Cavaleiro, C., Salgueiro, E., and Röhl, U., 2018. Data report: IODP Site U1387: the revised splice between Sections U1387B-18X-3 and U1387C-8R-3 (>171.6 mcd). In Stow, D.A.V., Hernández-Molina, F.J., Alvarez Zarikian, C.A., and the Expedition 339 Scientists, Proceedings of the Integrated Ocean Drilling Program, 339: Tokyo (Integrated Ocean Drilling Program Management International, Inc.).

doi:10.2204/iodp.proc.339.204.2018

2Divisão de Geologia e Georecursos Marinhos, Instituto Português do Mar e da Atmosfera (IPMA), Rua Alfredo Magalhães Ramalho 6, 1495-006 Lisboa, Portugal. Correspondence author: antje.voelker@ipma.pt

${ }^{3}$ Also at CCMAR, Centro de Ciencias do Mar, Universidade do Algarve, Campus de Gambelas, 8005-139, Faro, Portugal.

${ }^{4}$ Department of Biogeochemistry, Japan Agency for Marine-Earth Science and Technology (JAMSTEC), Yokosuka 237-0061, Japan.

${ }^{5}$ Also at Instituto Andaluz de Ciencias de la Tierra (CSIC-UGR), Avenida de las Palmeras 4, 18071 Amilla, Spain.

${ }^{6}$ Sedimentology and Marine Paleoenvironmental Dynamics, Institute of Earth Sciences, Heidelberg University, 69120 Heidelberg, Germany.

${ }^{7}$ Also at MARUM, Center for Marine Environmental Sciences, Universität Bremen, Leobener Strasse, 28355 Bremen, Germany.

\section{Abstract}

The Expedition 339 shipboard splice of Integrated Ocean Drilling Program (IODP) Site U1387 deeper than 155 meters composite depth (mcd) is based on a composite of the magnetic susceptibility and natural gamma radiation data. When generating high-resolution paleoceanographic reconstructions for the Mid-Pleistocene Transition and early Pleistocene sections of Site U1387, it quickly became obvious that proxy data misfits existed at several splice transitions. Thus, a revised splice was generated for Site U1387 below Core 339-U1387B-18X based on X-ray fluorescencederived element records (e.g., $\ln [\mathrm{Fe} / \mathrm{Ca}])$ and the stable isotope records obtained for planktonic and benthic foraminifers. Corrections were needed at most of the splice transitions below Core 339-U1387A-19X, with adjustments ranging from a few centimeters to several meters. In addition, Core 339-U1387A-33X and sections of Core $36 \mathrm{X}$ were integrated into the revised splice to replace Core 339-U1387C-2R and sections of Core 5R, respectively. The replacement of Core 339-U1387C-2R with Core 339-U1387A$33 \mathrm{X}$ is an option for the intended paleoceanographic research and not essential for lower resolution studies. The splice tie point table, therefore, also includes an option for a splice that retains Core 339-U1387C-2R. The extensive revision of the shipboard splice reveals that making a splice for sediment sequences rich in contourite layers and coring disturbances (biscuiting in the extended core barrel cores) can be tricky and that data misfits at splice transitions are not necessarily a data problem but could indicate a splice problem.

\section{Introduction}

During Integrated Ocean Drilling Program (IODP) Expedition 339, Mediterranean Outflow, IODP Site U1387 $\left(36.8^{\circ} \mathrm{N}, 7.7^{\circ} \mathrm{W}\right.$; $559 \mathrm{~m}$ water depth; Fig. F1) was drilled into the contourite deposits of the Faro Drift (see the Expedition 339 summary chapter [Expedition 339 Scientists, 2013a). The Faro Drift was built up by activity of the Mediterranean Outflow Water (MOW), the upper core of which is directly influencing Site U1387 (see the Site U1387 chapter [Expedition 339 Scientists, 2013b]; Voelker et al., 2015). Present-day surface waters in the region are of subtropical origin and transported by the eastern branch of the Azores Current (far offshore) and the eastbound Gulf of Cadiz Slope Current, 
an open-ocean current located along the southern Iberian margin (Peliz et al., 2009) (Fig. F1).

At Site U1387, three holes were drilled. Holes U1387A and U1387B were drilled with the advanced piston corer (APC) and extended core barrel (XCB) coring systems, and Hole U1387C was drilled with the rotary core barrel (RCB) system. The XCB-drilled cores, starting with Cores 339-U1387A-7X and 339U1387B-6X, show persistent coring disturbances, (i.e., biscuits) (see the Site U1387 chapter [Expedition 339 scientists, 2013b]). During the expedition, a shipboard splice was constructed based on magnetic susceptibility and natural gamma radiation (NGR) data at resolutions of $2.5 \mathrm{~cm}$ and $20 \mathrm{~cm}$, respectively. Deeper than 155 meters composite depth (mcd), the shipboard splice is based on the combination of the magnetic susceptibility and NGR signals because the magnetic susceptibility data had weak signals and might be anomalous because of the biscuiting (see Stratigraphic correlation in the Site U1387 chapter [Expedition 339 Scientists, 2013b]).

Within the Surface and Mediterranean Outflow Water Dynamics in the Gulf of Cadiz during the Pleistocene (MOWCADYN) project, a multiproxy study was performed to reconstruct surface water and MOW changes in the interval between marine isotope Stages (MISs) 16 and 48, encompassing samples from Sections 339-U1387B-18X-3 through 339-U1387C8R-3 (i.e., between 171.68 and 389.19 mcd). However, when the results of the stable isotope analyses, among others, became available, it was evident that mismatches occurred in the proxy records at several splice transitions. Additional off-splice samples were therefore analyzed to increase/maximize the overlap between cores at the splice transitions, leading to the revised splice presented here.

\section{Materials and methods}

The analytical measurements were done on the working and archive halves of Site U1387 core. Samples for discrete analyses were taken from the working halves, including core catcher sections, with great care taken to avoid sampling the fillings between the biscuits in the XCB cores of Holes U1387A and $\mathrm{U} 1387 \mathrm{~B}$. The average sample resolution is $12-13$ $\mathrm{cm}$, although the actual sample-to-sample distance can be between 9 and $17 \mathrm{~cm}$ or increase to $\sim 6 \mathrm{~cm}$ in the higher resolution interval across Termination $\mathrm{X}$ (MIS 21-22 transition). The samples were prepared in the Laboratory for Sedimentology and Micropaleontology of the Marine Geology Division of Instituto Português do Mar e da Atmosfera (IPMA) (formerly at Laboratório Nacional de Energia e Geologia [LNEG]) following the established procedure (i.e., weighing, freeze drying, washing through $63 \mu \mathrm{m}$ mesh, and drying and weighing of the $>63 \mu \mathrm{m}$ fraction) (Voelker et al., 2015). The weight percent of sand $>63$ $\mu \mathrm{m}$ was calculated by dividing the dry weight of the washed sample by the weight of the $>63 \mu \mathrm{m}$ fraction.

For stable isotope analysis of Globigerina bulloides shells, 8-12 clean specimens were collected from the $>250 \mu \mathrm{m}$ fraction. The samples were analyzed with Finnigan MAT-251 and MAT-252 mass spectrometers, each coupled to an automated Kiel I carbonate preparation system, at the Center for Marine Environmental Sciences (MARUM; University Bremen, Germany). The mass spectrometers' long-term precision is $\pm 0.07 \%$ o for $\delta^{18} \mathrm{O}$ based on repeated analyses of internal (Solnhofen limestone) and external (NBS19) carbonate standards. Stable isotopes in benthic foraminifer shells of Planulina ariminensis or Cibicidoides pachyderma were analyzed. Samples were either measured at MARUM (majority of samples) or at the Geozentrum Nordbayern (Erlangen, Germany). For further details, see Voelker et al. (2015) because benthic isotope data are used here mostly to evaluate the short coring gaps.

The X-ray fluorescence (XRF) core scanner data were collected every $3 \mathrm{~cm}$ downcore over a $1.2 \mathrm{~cm}^{2}$ area with a downcore slit size of $10 \mathrm{~mm}$ and three separate runs using generator settings of 10,30 , and 50 $\mathrm{kV}$ and a current of $0.2,1.0$, and $1.0 \mathrm{~mA}$, respectively (Bahr et al., 2014; Voelker et al., 2015). Sampling time was $30 \mathrm{~s}$ directly at the split-core surface of the archive half using XRF Core Scanner II (AVAATECH Serial Number 2) at MARUM. The split-core surface was covered with a $4 \mu \mathrm{m}$ thin SPEXCerti Prep ultralene foil to avoid contamination of the XRF measurement unit and desiccation of the sediment. The majority of data reported here have been acquired by a Canberra X-PIPS silicon drift detector (SDD; Model SXD15C-150-500) with $150 \mathrm{eV}$ X-ray resolution, the Canberra DAS 1000 digital spectrum analyzer, and an Oxford Instruments 100W Neptune X-ray tube with rhodium (Rh) target material. In January 2015, this tube was replaced by an Oxford Instruments XTF5011 X-ray tube 93057, which affected the analysis of some of the off-shipboard splice sections. The tube substitution had, however, no effect on the $\ln (\mathrm{Fe} / \mathrm{Ca})$ results shown here (no offsets observed between sections analyzed prior to or after January 2015). The XRF scanner's raw data spectra were processed by X-ray spectra analysis by a iterative leastsquare software (WIN AXIL) package from Canberra Eurisys. Following Bahr et al. (2014, 2015), we are presenting the XRF data as the natural logarithm of the $\mathrm{Fe} / \mathrm{Ca}$ ratio. Small gaps in the $\ln (\mathrm{Fe} / \mathrm{Ca})$ splice are caused by "missing" sections (i.e., sections that were added into the splice during late stages of the revi- 
sions, when XRF measurements had been "completed").

\section{Results}

The revised splice (Fig. F2) covers the complete interval between Cores 339-U1387B-18X and 339U1387C-8R, which is the last core in the (shipboard) splice and the first core in the single-cored section of Hole U1387C (see the Site U1387 chapter [Expedition 339 Scientists, 2013b]). The revised splice has a corrected mcd (c-mcd) depth scale (i.e., cores are shifted relative to each other without any correction for compression/expansion). Deeper than $171.6 \mathrm{mcd}$ (older than MIS 16), the splice includes 41 transitions, of which only 6 did not need to be adjusted (Table T1). Shifts at the other transitions range from 0.01 to $5.56 \mathrm{~m}$, with just a few having a negative value. For the interval between Cores 339-U1387B26X and 339-U1387A-29X, the relative shifts published in Voelker et al. (2015) remain the same; the absolute c-mcd values, however, changed due to additional corrections above. Table T2 lists the correction needed to convert mcd to c-mcd values for each core within the revised splice. For Core 339-U1387C$8 \mathrm{R}$, this value exceeds $50 \mathrm{~m}$, highlighting how strongly the splice was modified from the shipboard version.

The revisions of the splice transitions are based on signals in the $\ln (\mathrm{Fe} / \mathrm{Ca})$ and stable isotope records (Figs. F2, F3), although the weight percent sand data and, in one case, the alkenone-derived sea-surface temperate (SST) data (Voelker et al., 2017) were also considered, if necessary (Table T1). In general, the combined $\ln (\mathrm{Fe} / \mathrm{Ca})$ and isotopic signals are taken into account. However, if only one such record (or additional data) is used, this is noted in Table T1. In a few cases, the revised splice tie point is based on the benthic foraminifer isotope signal because XRF and $\delta^{18} \mathrm{O}$ G. bulloides data are missing (not measured/ not possible to measure) or inconclusive (e.g., Fig. F2F versus F3E). The benthic foraminifer isotope records are particularly important in the cases where a core needs to be appended to the core catcher of the previous core (Fig. F3). In these cases, it was impossible to generate proxy records that overlap, which is indicated by the comment "short coring gap" in Table T1. Many of these cases are associated with a pronounced benthic $\delta^{13} \mathrm{C}$ minimum (Fig. F3A-F3D), which is often related to an insolation maximum (e.g., Voelker et al., 2015). The clear trends visible in the benthic $\delta^{13} \mathrm{C}$ records allow the estimation that most of the coring gaps are minimal ( 1-2 samples/ $12-25 \mathrm{~cm} /<600 \mathrm{y})$. An exception is the gap at the Section 339-U1387A-27X-CC to 28X-1 transition
(Fig. F3B), which encompasses 2.25 ky (Voelker et al., 2015). Contrary to the shipboard splice, the revised splice also includes core catcher samples, not only in the cases where cores are appended but also as regular tie points (Table T1; e.g., Sections 339U1387B-28X-CC through 339-U1387A-29X-1).

The shipboard splice incorporates a tie point from Core 339-U1387C-5R to Core 339-U1387B-36X. Neither the XRF nor the stable isotope records of both cores revealed any overlap, although core catcher samples of Core 339-U1387C-5R were included (Fig. F2G). To solve this problem, sections of Core 339U1387A-36X were analyzed and subsequently incorporated into the splice. Both cores include a prominent contourite layer; therefore, it was easy to splice the two records based on their weight percent records (Fig. F4A), whereby the uppermost level of the weight percent sand maximum (i.e., $408.27 \mathrm{c}-\mathrm{mcd}$ ) was chosen as a tie point. The planktonic and benthic foraminifer stable isotope records of both cores are also very similar (Fig. F4B, F4C) but highlight, like the weight percent sand data, the apparent lower sedimentation rate in Core 339-U1387C-5R, which is most likely an artifact caused by RCB coring (i.e., some sediment being washed out). With the core catcher of Core 339-U1387A-36X being included in the revised splice, this record reaches a little bit further back in time than the Core 339-U1387C-5R data, allowing the minimization of the coring gap that exists at the Core 339-U1387A-36X to Core 339U1387B-36X transition (Fig. F3F).

After the study of Site U1385 by Birner et al. (2016) was published, it was obvious that the existing $\delta^{18} \mathrm{O}$ G. bulloides record of Site U1387 lacked several of the millennial-scale oscillations during MIS 40. In the shipboard splice of Site U1387, the MIS 40 interval is covered by Core 339-U1387C-2R. Because of the previous experience of RCB-drilled cores potentially losing some material (e.g., Core 339-U1387A-36X versus Core 339-U1387C-5R) and thus climate signals, Core 339-U1387A-33X was analyzed completely to verify if this core should be included in the splice instead. The two cores cover the same time interval, but as expected the Core 339-U1387A-33X record shows much more variability than that of Core 339U1387C-2R (Fig. F2E). So, Core 339-U1387C-2R was replaced by Core 339-U1387A-33X in the revised splice, which is the preferred version of the revised splice. The splice tie point from Core 339-U1387B$32 \mathrm{X}$ to Core $339-\mathrm{U} 1387 \mathrm{~A}-33 \mathrm{X}$ is based on perfectly matching benthic isotope records (not shown) because $G$. bulloides was rare/absent in most samples of the top half of Section 339-U1387A-33X-1 (generating the apparent gap in the splice record shown in Fig. F2E). Because a previous version of the revised 
splice contained corrections for the two tie points related to Core 339-U1387C-2R, Tables T1 and T2 also provide information on an optional revised splice that includes this core.

\section{Acknowledgments}

The samples for this study were provided by the Integrated Ocean Drilling Program (IODP) (2003-2013). The study was financially supported by the Fundação para a Ciência e a Tecnologia (FCT) through projects MOWCADYN (PTDC/MAR-PRO/ 3761/2012) and CCMAR (UID/Multi/04326/2013), Investigador FCT grant to A.V. (IF/01500/2014), doctoral fellowships to A.R. (SFRH/BD/78016/2011) and C.C. (SFRH/BD/84187/2012), and a postdoctorate fellowship to E.S. (SFRH/BPD/111433/2015). XRF analyses were funded by a Spanish Ministerio de Economia y Competitividad (MINECO) grant (CTM 2011-24079), Deutsche Forschungsgemeinschaft (DFG), and MARUM. We thank Vera Lukies for her help during XRF measurements. F.J.J.E. received support from the SCORE Project (CGL2016-80445-R; AEI/FEDER, UE) and thanks C. Escutia and project CTM2014-60451-C2-1-P for support. A.V. also wholeheartedly thanks Walter Hale, Alex Wülbers, and the various student helpers at the Bremen Core Repository for fulfilling the "neverending" requests for additional samples that were needed to correct the splice. We thank Tim van Peer for his helpful review. The data shown here will be stored at the Pangaea data center in the future.

\section{References}

Bahr, A., Jiménez-Espejo, F.J., Kolasinac, N., Grunert, P., Hernández-Molina, F.J., Röhl, U., Voelker, A.H.L., Escutia, C., Stow, D.A.V., Hodell, D., and Alvarez-Zarikian, C.A., 2014. Deciphering bottom current velocity and paleoclimate signals from contourite deposits in the Gulf of Cádiz during the last 140 kyr: an inorganic geochemical approach. Geochemistry, Geophysics, Geosystems, 15(8):3145-3160. https://doi.org/10.1002/ 2014GC005356

Bahr, A., Kaboth, S., Jiménez-Espejo, F.J., Sierro, F.J., Voelker, A.H.L., Lourens, L., Röhl, U., Reichart, G.J., Escutia, C., Hernández-Molina, F.J., Pross, J., and Fried- rich, O., 2015. Persistent monsoonal forcing of Mediterranean Outflow Water dynamics during the late Pleistocene. Geology, 43(11):951-954. https://doi.org/ 10.1130/G37013.1

Birner, B., Hodell, D.A., Tzedakis, P.C., and Skinner, L.C., 2016. Similar millennial climate variability on the Iberian margin during two early Pleistocene glacials and MIS 3. Paleoceanography, 31(1):203-217. https:// doi.org/10.1002/2015PA002868

Expedition 339 Scientists, 2013a. Expedition 339 summary. In Stow, D.A.V., Hernández-Molina, F.J., Alvarez Zarikian, C.A., and the Expedition 339 Scientists, Proceedings of the Integrated Ocean Drilling Program, 339: Tokyo (Integrated Ocean Drilling Program Management International, Inc.). https://doi.org/10.2204/

iodp.proc.339.101.2013

Expedition 339 Scientists, 2013b. Site U1387. In Stow, D.A.V., Hernández-Molina, F.J., Alvarez Zarikian, C.A., and the Expedition 339 Scientists, Proceedings of the Integrated Ocean Drilling Program, 339: Tokyo (Integrated Ocean Drilling Program Management International, Inc.). https://doi.org/10.2204/

iodp.proc.339.105.2013

Peliz, A., Marchesiello, P., Santos, A.M.P., Dubert, J., TelesMachado, A., Marta-Almeida, M., and Le Cann, B., 2009. Surface circulation in the Gulf of Cadiz: 2. Inflowoutflow coupling and the Gulf of Cadiz slope current. Journal of Geophysical Research: Oceans, 114(C3):C03011. https://doi.org/10.1029/2008jc004771

Voelker, A., Rodrigues, T., Padilha, M., Jimenez-Espejo, F.J., Salgueiro, E., and Kuhnert, H., 2017. Early to middle Pleistocene climate records off Southern Iberia reveal two types of interglacial climate evolution. Geophysical Research Abstracts, 19:EGU2017-10456. https://meetingorganizer.copernicus.org/EGU2017/EGU201710456.pdf

Voelker, A.H.L., Salguiero, E., Rodrigues, T., Jiminez-Espejo, F.J., Bahr, A., Alberto, A., Loureiro, I., Padilha, M., Rebotim, A., and Röhl, U., 2015. Mediterranean Outflow and surface water variability off southern Portugal during the Mid-Pleistocene Transition-a snapshot at Marine Isotope Stages 29 to 34 (1010-1135 ka). Global and Planetary Change, 133:223-237. https://doi.org/10.1016/ j.gloplacha.2015.08.015

Initial receipt: 16 April 2018

Acceptance: 6 August 2018

Publication: 19 October 2018

MS 339-204 
Figure F1. Northern Gulf of Cadiz with location of Site U1387 and major currents. GCC = Gulf of Cadiz Current, u-MOW = upper Mediterranean Outflow Water.

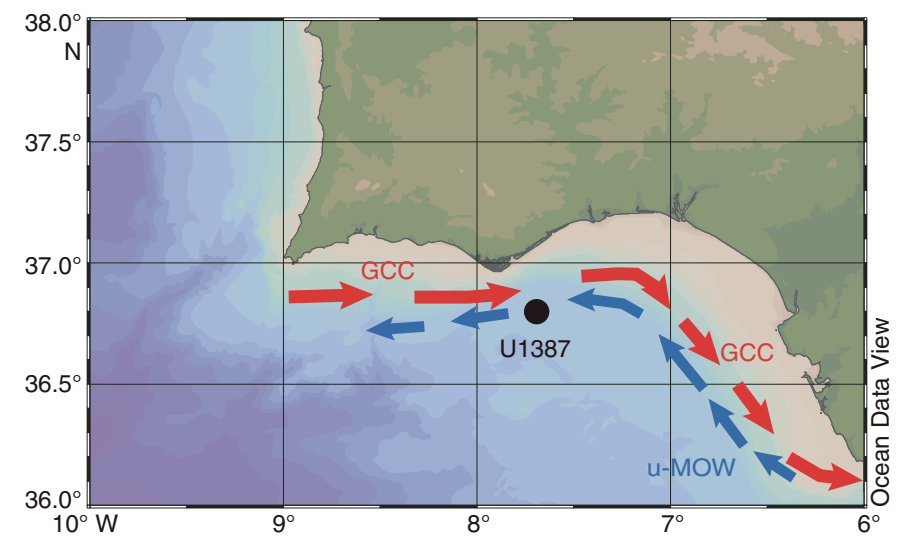


A.H.L. Voelker et al.

Data report: Site U1387 revised splice

Figure F2. Revised splice vs. corrected mod (c-mcd), with (from bottom to top) XRF-derived ln(Fe/Ca), Globigerina bulloides (Gob.) $\delta^{18} \mathrm{O}$ records for the respective cores, and the final splice. Dark blue $=$ Hole U1387A data, magenta $=$ Hole U1387B data, green $=$ Hole U1387C data. A19, B18, C2, etc.$=$ hole and core number. VPDB $=$ Vienna Peedee belemnite. A. 170-210 c-mcd. B. 210-250 c-mcd. C. 250-290 c-mcd. D. 290-330 c-mcd. (Contined on next page.)

A
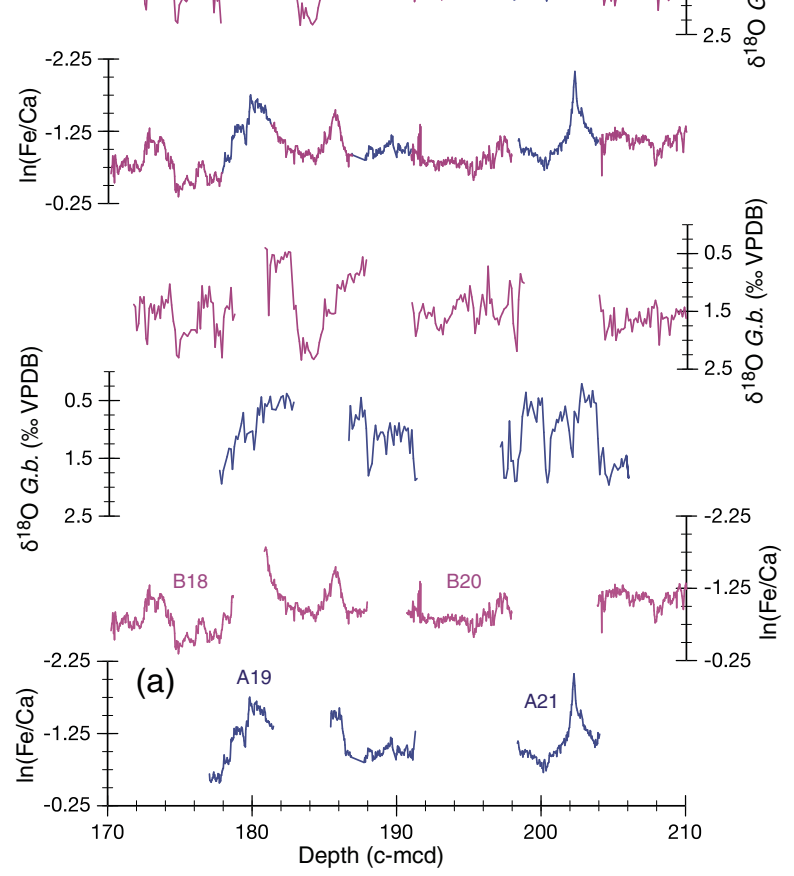

C

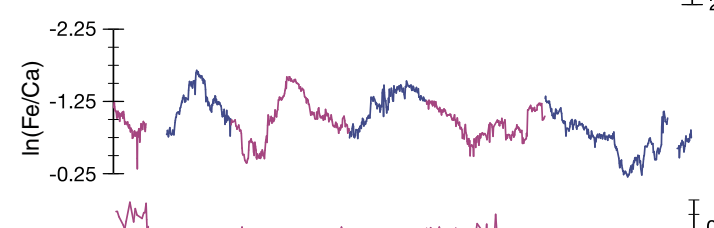

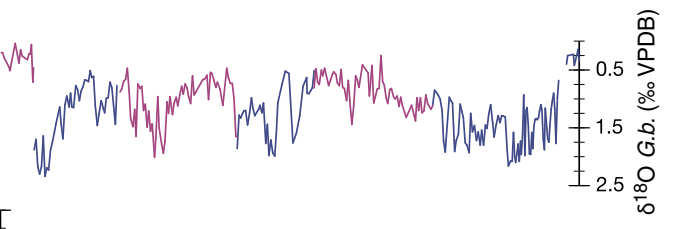

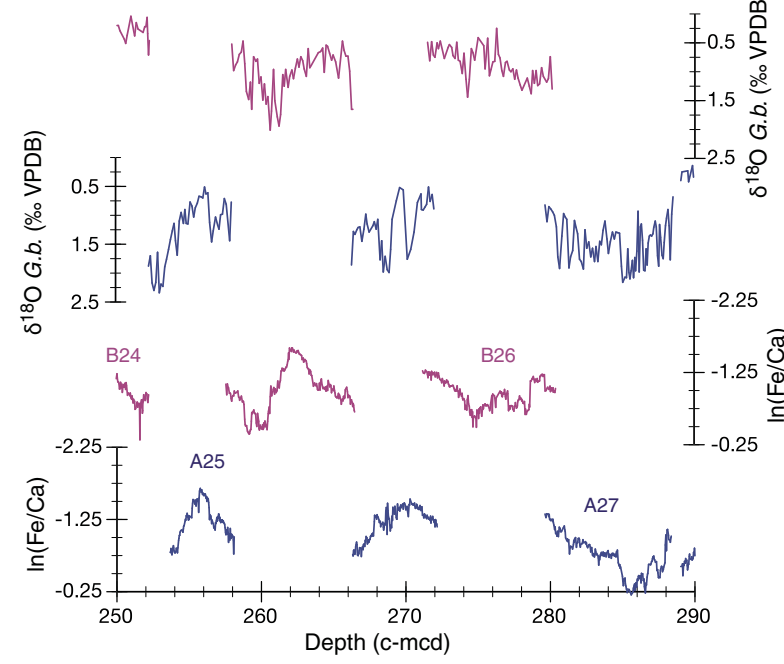

B

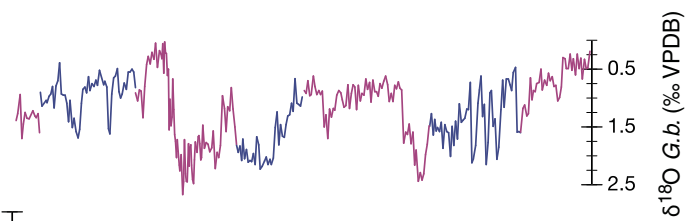
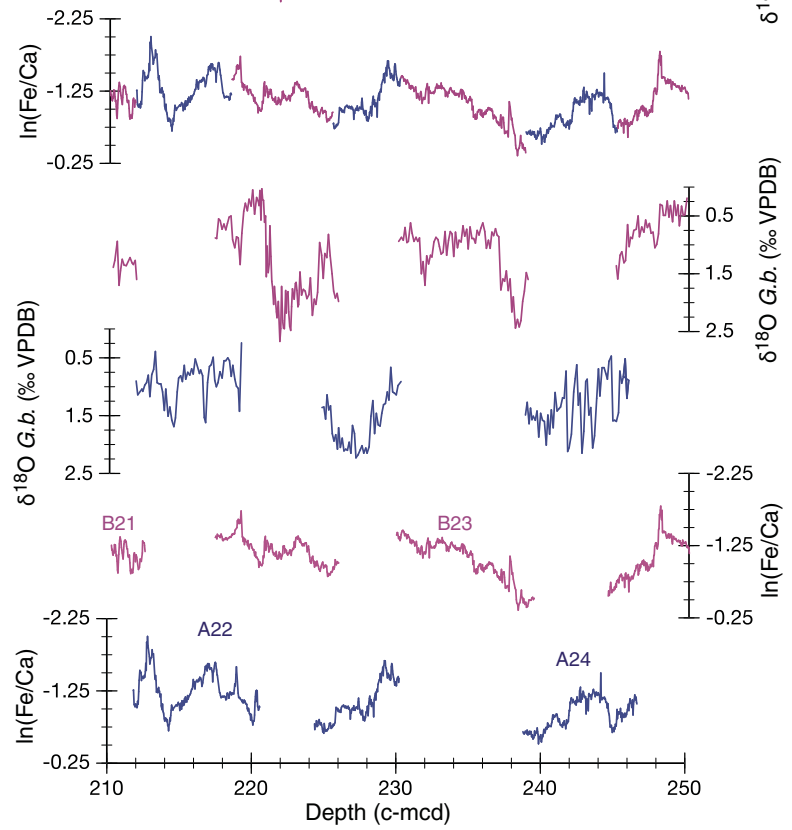

D

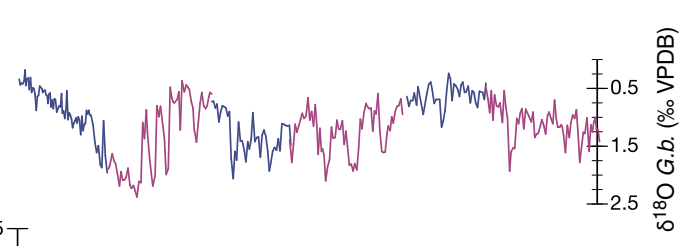

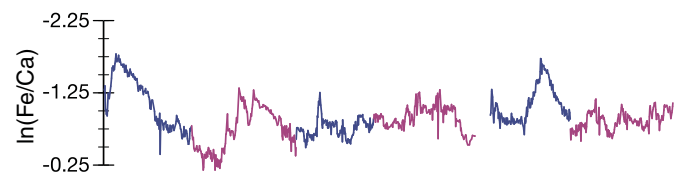

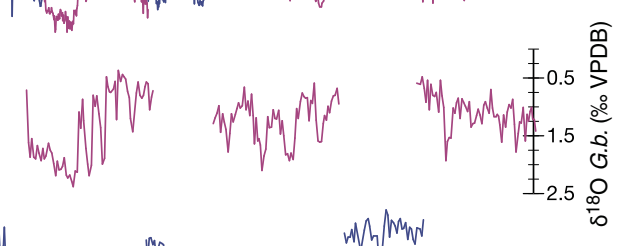

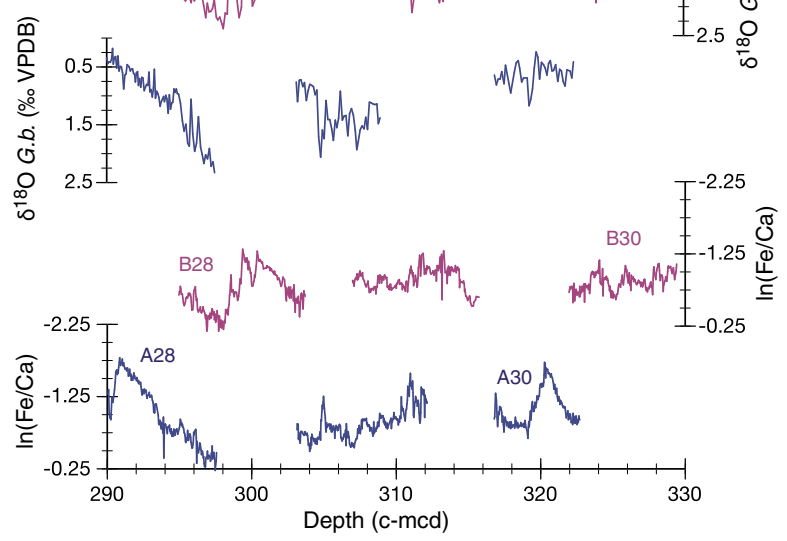

Proc. IODP | Volume 339

6 
Figure F2 (continued). E. 330-370 c-mcd. Dashed lines indicate respective climatic features in the $\delta^{18} \mathrm{O}$ records for Cores 339-U1387A-33X and 339-U1387C-2R. F. 370-410 c-mcd. G. 410-450 c-mcd.

$\mathbf{E}$

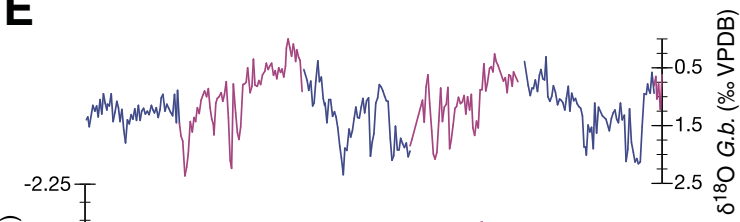

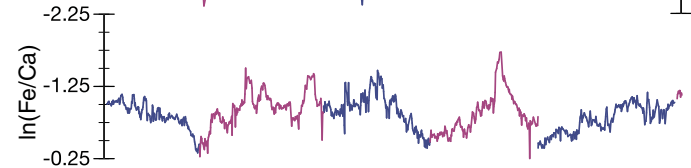

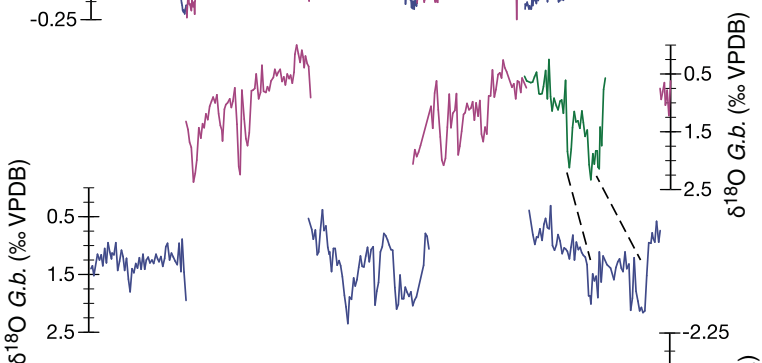

(b)

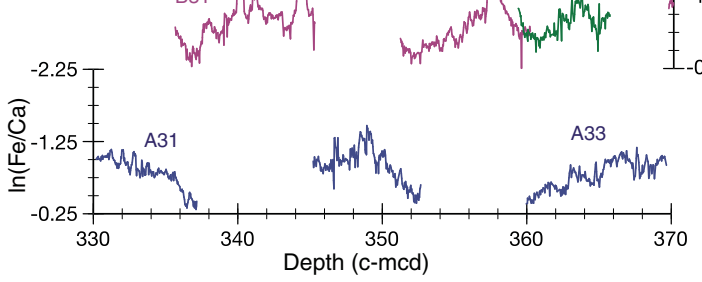

$\mathbf{F}$

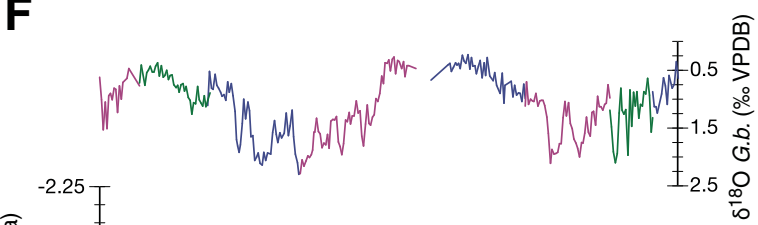

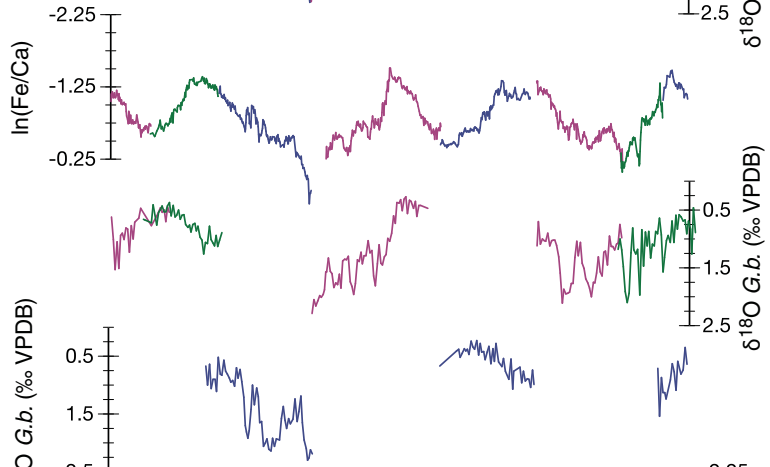

每 2.5

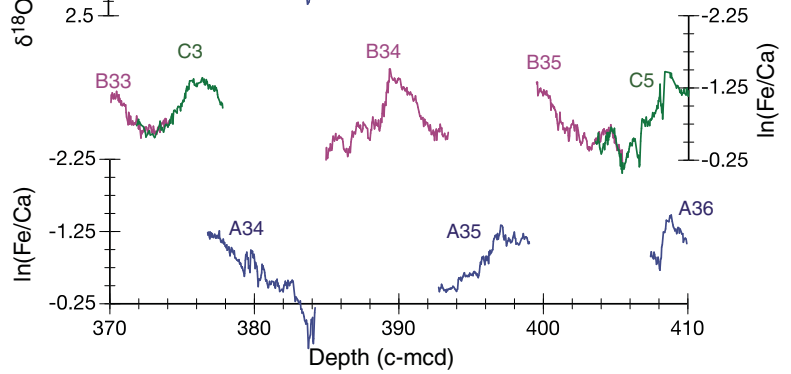

G

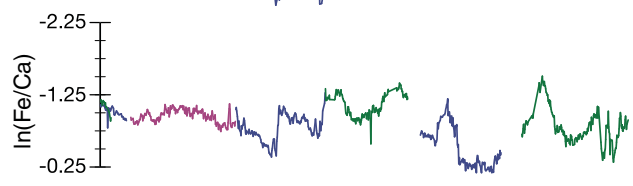

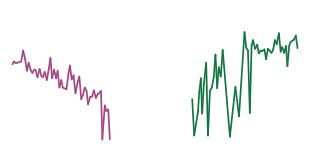

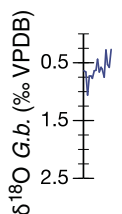

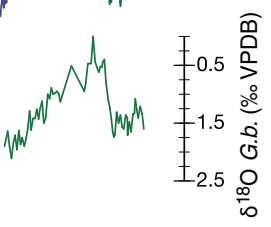

C5 B B 1 (1)<smiles>CN(N)c1ccccc1</smiles>

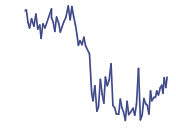

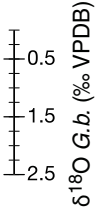

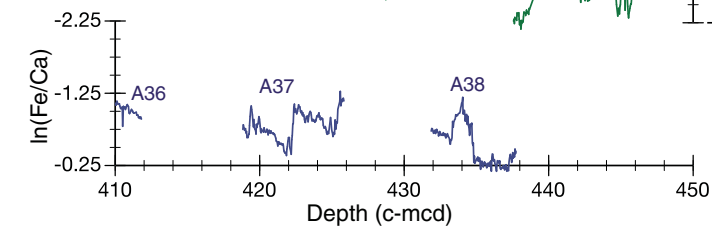


Figure F3. Benthic $\delta^{18} \mathrm{O}$ and $\delta^{13} \mathrm{C}$ records for transitions where short coring gaps are indicated in Table T1 (i.e., where no overlapping sampling was possible and the top of the subsequent core in the splice is appended to the core catcher of the core above). B24, A25, A27, A28, etc. = hole and core number. VPDB = Vienna Peedee belemnite. A. Transition from Core 339-U1387B-24X to Core 339-U1387A-25X. B. Transition from Core 339U1387A-27X to Core 339-U1387A-28X. C. Transition from Core 339-U1387B-29X to Core 339-U1387A-30X. D. Transition from Core 339-U1387B-31X to Core 339-U1387A-32X. E. Transition from Core 339-U1387B-34X to Core 339-U1387A-35X. F. Transition from Core 339-U1387A-36X to Core 339-U1387B-36X.

\section{A}

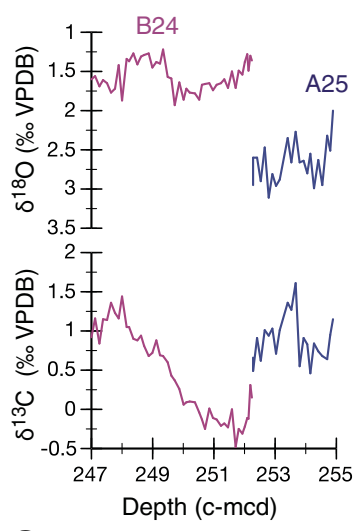

C

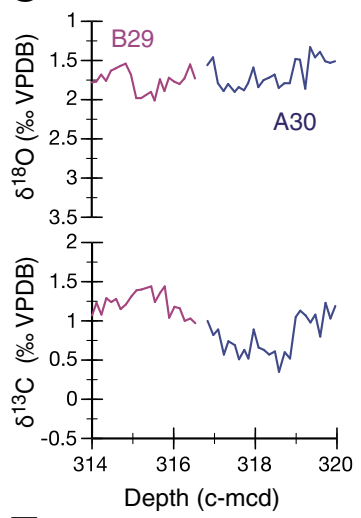

E
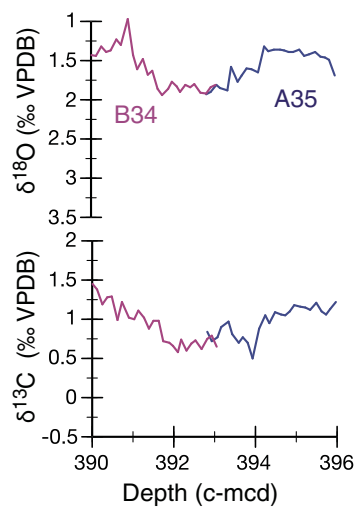

B

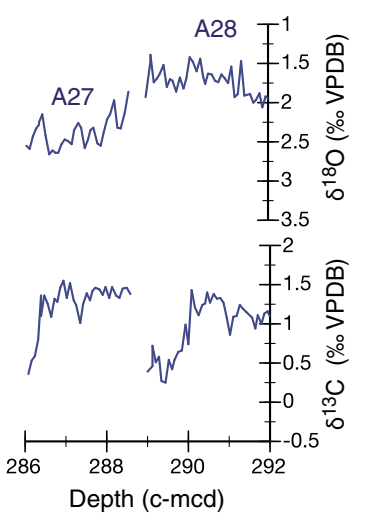

D
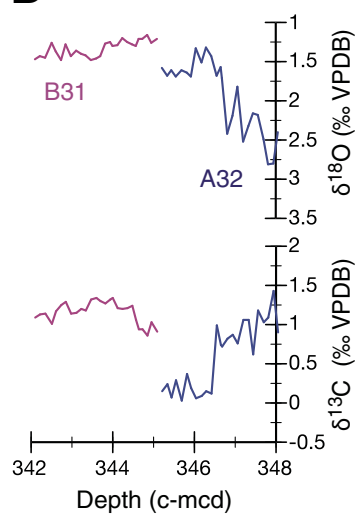

$\mathbf{F}$

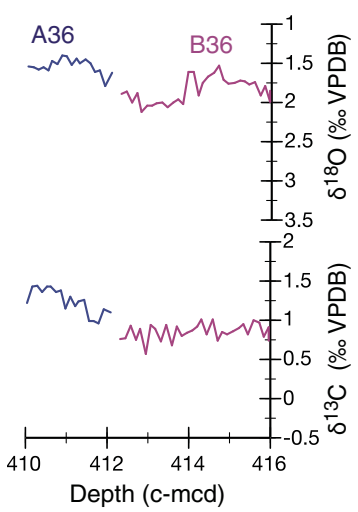


Figure F4. Comparison between the (A) $>63 \mu \mathrm{m}$ sand fraction and (B) Globigerina bulloides (G.b.) $\delta^{18} \mathrm{O}$ and (C) benthic $\delta^{18} \mathrm{O}$ records of Cores 339-U1387C-5R (green) and 339-U1387A-36X (dark blue) on the corrected mcd (c-mcd) scale. The tie point for the splice transition was placed at the uppermost level of the sand maximum (408.27 c-mcd). The similarity between the planktonic and benthic $\delta^{18} \mathrm{O}$ records indicates that both cores record nearly the same time interval but with higher resolution and apparently extending slightly farther back in time in Core 339-U1387A-36X. Note that the records of both cores extend into the respective core catchers. VPDB = Vienna Peedee belemnite.
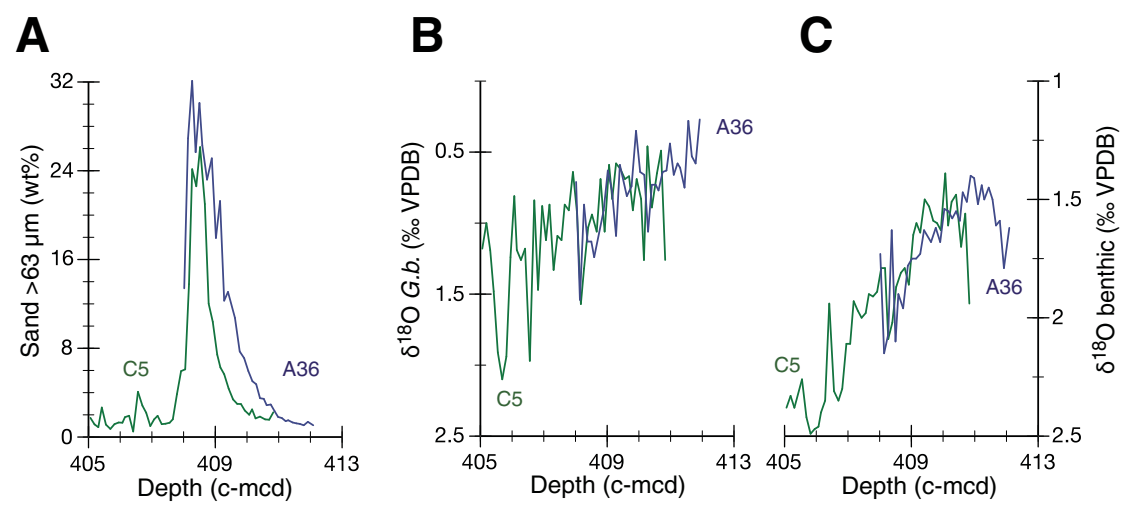
Table T1. Tie points of revised splice, Site U1387.

\begin{tabular}{|c|c|c|c|c|}
\hline $\begin{array}{l}\text { Hole, core, section, } \\
\text { interval }(\mathrm{cm})\end{array}$ & & $\begin{array}{l}\text { Hole, core, section, } \\
\text { interval }(\mathrm{cm})\end{array}$ & Offset (m) & Comments \\
\hline \multicolumn{5}{|c|}{ Preferred revised splice including Core 339-U1387A-33X } \\
\hline U1387B-18X-7, 22 & Tie to & U1387A-19X-2, 85 & 0.00 & \multirow{6}{*}{ Shipboard splice tie } \\
\hline U1387A-19X-4, 126 & Tie to & U1387B-19X-2, 52 & 0.19 & \\
\hline U1387B-19X-6, 10 & Tie to & U1387A-20X-2, 144 & 0.00 & \\
\hline U1387A-20X-5, 103 & Tie to & U1387B-20X-1, 52 & 0.36 & \\
\hline U1387B-20X-5, 128 & Tie to & U1387A-21X-1, 89 & 0.81 & \\
\hline U1387A-21X-5, 109 & Tie to & U1387B-21X-1, 11 & 0.00 & \\
\hline U1387B-21X-6, 56 & Tie to & U1387A-22X-2, 6 & 1.39 & \multirow[t]{2}{*}{ Based on XRF data } \\
\hline U1387A-22X-6, 64 & Tie to & U1387B-22X-1, 125 & 1.86 & \\
\hline U1387B-22X-6, 74 & Tie to & U1387A-23X-1, 109 & 1.94 & \multirow[t]{2}{*}{ Based on $\delta^{18} \mathrm{O}$ Globigerina bulloides data } \\
\hline U1387A-23X-4, 128 & Tie to & U1387B-23X-1, 38.5 & 0.00 & \\
\hline U1387B-23X-7, 42 & Tie to & U1387A-24X-1, 3 & 1.75 & \multirow{2}{*}{ Based on XRF and SST data } \\
\hline U1387A-24X-5, 138 & Tie to & U1387B-24X-2, 72 & 0.61 & \\
\hline U1387B-24X-CC, 26 & Append to & U1387A-25X-1, 10 & 2.01 & \multirow[t]{3}{*}{ Short coring gap } \\
\hline U1387A-25X-4, 150 & Tie to & U1387B-25X-1, 56 & 0.00 & \\
\hline U1387B-25X-6, 125 & Tie to & U1387A-26X-1, 5 & 2.94 & \\
\hline U1387A-26X-4, 87 & Tie to & U1387B-26X-1, 52 & 0.96 & \multirow[t]{3}{*}{ Based on XRF data } \\
\hline U1387B-26X-7, 21 & Tie to & U1387A-27X-1, 50 & 2.52 & \\
\hline U1387A-27X-CC, 16 & Append to & U1387A-28X-1, 0 & 0.00 & \\
\hline U1387A-28X-5, 113 & Tie to & U1387B-28X-2, 119 & 0.14 & \multirow[t]{2}{*}{ Based on XRF data } \\
\hline U1387B-28X-CC, 37 & Tie to & U1387A-29X-1, 24 & 2.79 & \\
\hline U1387A-29X-5, 66 & Tie to & U1387B-29X-2, 36 & -0.15 & Based on XRF data \\
\hline U1387B-29X-CC, 21 & Append to & U1387A-30X-1, 0 & 3.28 & \multirow{4}{*}{ Short coring gap } \\
\hline U1387A-30X-4, 110 & Tie to & U1387B-30X-2, 39 & 0.21 & \\
\hline U1387B-30X-CC, 22 & Tie to & U1387A-31X-1, 5 & 1.84 & \\
\hline U1387A-31X-5, 49 & Tie to & U1387B-31X-1, 114 & 0.29 & \\
\hline U1387B-31X-CC, 32 & Append to & U1387A-32X-1, 0 & 4.02 & \multirow[t]{2}{*}{ Short coring gap } \\
\hline U1387A-32X-5, 139 & Tie to & U1387B-32X-2, 103 & 1.43 & \\
\hline U1387B-32X-7, 102 & Tie to & U1387A-33X-1, 16 & 3.59 & \multirow[t]{4}{*}{ Based on benthic $\delta^{18} \mathrm{O}$ data } \\
\hline U1387A-33X-CC, 7 & Tie to & U1387B-33X-1, 23 & 3.52 & \\
\hline U1387B-33X-4, 14 & Tie to & U1387C-3R-1, 101 & -1.56 & \\
\hline U1387C-3R-4, 123 & Tie to & U1387A-34X-3, 76 & 0.46 & \\
\hline U1387A-34X-CC, 11 & Tie to & U1387B-34X-1, 4 & 5.52 & Based on $\delta^{18} \mathrm{O}$ Globigerina bulloides data \\
\hline U1387B-34X-7, 67 & Tie to & U1387A-35X-3, 12 & 0.32 & \multirow[t]{3}{*}{ Based on benthic $\delta^{18} \mathrm{O}$ data } \\
\hline U1387A-35X-CC, 38 & Tie to & U1387B-35X-2, 2 & 4.39 & \\
\hline U1387B-35X-5, 138 & Tie to & U1387C-5R-3, 27 & -0.07 & \\
\hline U1387C-5R-5, 23, & Tie to & U1387A-36X-5, 90 & -2.47 & \multirow{3}{*}{$\begin{array}{l}\text { Based on wt\% sand data } \\
\text { Short coring gap }\end{array}$} \\
\hline U1387A-36X-CC, 25 & Append to & U1387B-36X-1, 0 & 4.86 & \\
\hline U1387B-36X-5, 127 & Tie to & U1387A-37X-2, 56 & -0.01 & \\
\hline U1387A-37X-6, 77 & Tie to & U1387C-7R-1, 93 & 0.40 & \multirow[t]{2}{*}{ Based on $\delta^{18} \mathrm{O}$ Globigerina bulloides and wt $\%$ sand data } \\
\hline U1387C-7R-5, 65 & Tie to & U1387A-38X-1, 93 & 1.86 & \\
\hline U1387A-38X-6, 133 & Tie to & U1387C-8R-2, 13 & 0.94 & Based on $\delta^{18} \mathrm{O}$ Globigerina bulloides data \\
\hline \multicolumn{5}{|c|}{ Revised splice using Core 339-U1387C-2R } \\
\hline U1387B-32X-7, 105 & Tie to & U1387C-2R-3, 85 & 0.00 & \multirow[t]{2}{*}{ Shipboard splice tie } \\
\hline U1387C-2R-7, 25 & Tie to & U1387B-33X-1, 5 & 3.20 & \\
\hline
\end{tabular}

Offset between $\mathrm{mcd}$ and corrected $\mathrm{mcd}$ is at the respective transition. $\mathrm{XRF}=\mathrm{X}$-ray fluorescence, $\mathrm{SST}=$ sea-surface temperature . 
Table T2. Offsets between corrected mcd (c-mcd) and mbsf and mcd depths of samples from cores within the revised splice, Site U1387.

\begin{tabular}{|c|c|c|c|c|c|}
\hline Core & $\begin{array}{l}\text { Depth } \\
\text { (mbsf) }\end{array}$ & $\begin{array}{l}\text { Depth } \\
\text { (mcd) }\end{array}$ & $\begin{array}{l}\text { Depth } \\
\text { (c-mcd) }\end{array}$ & $\begin{array}{c}\text { Offset } \\
\text { between } \\
\text { c-mcd and mbsf } \\
(\mathrm{m})\end{array}$ & $\begin{array}{l}\text { Offs } \\
\text { betwe } \\
\text { c-mcd } \\
\text { mcd }\end{array}$ \\
\hline \multicolumn{6}{|c|}{$\begin{array}{l}\text { Preferred revised splice including Core } 339-U 1387 A-33 X \\
339-U 1387 A-\end{array}$} \\
\hline $19 x$ & 163.25 & 177.86 & 177.86 & 14.61 & 0.0 \\
\hline $20 x$ & 173.33 & 186.66 & 186.85 & 13.52 & 0.1 \\
\hline $21 X$ & 180.99 & 196.53 & 197.70 & 16.71 & 1.1 \\
\hline $22 x$ & 190.08 & 209.28 & 211.84 & 21.76 & 2.5 \\
\hline $23 x$ & 200.29 & 219.05 & 225.41 & 25.12 & 6.3 \\
\hline $24 X$ & 208.83 & 230.67 & 238.78 & 29.95 & 8.1 \\
\hline $25 X$ & 218.50 & 241.51 & 252.24 & 33.74 & 10.7 \\
\hline $26 X$ & 228.05 & 252.66 & 266.33 & 38.28 & 13.6 \\
\hline $27 X$ & 238.10 & 262.71 & 279.86 & 41.76 & 17.1 \\
\hline $28 \mathrm{X}$ & 247.20 & 271.81 & 288.96 & 41.76 & 17.1 \\
\hline $29 x$ & 257.04 & 283.25 & 303.33 & 46.29 & 20.0 \\
\hline $30 x$ & 266.40 & 293.49 & 316.70 & 50.30 & 23.2 \\
\hline $31 x$ & 276.05 & 304.90 & 330.16 & 54.11 & 25.2 \\
\hline $32 x$ & 285.60 & 315.60 & 345.17 & 59.57 & 29.0 \\
\hline $33 x$ & 295.36 & 325.43 & 360.02 & 64.66 & 34.5 \\
\hline $34 X$ & 308.30 & 340.47 & 377.48 & 69.18 & 37.0 \\
\hline $35 x$ & 317.12 & 349.97 & 392.82 & 75.70 & 42.8 \\
\hline $36 x$ & 329.44 & 363.57 & 408.27 & 78.83 & 44.7 \\
\hline $37 X$ & 335.26 & 369.79 & 419.34 & 84.08 & 49.5 \\
\hline $38 \mathrm{X}$ & 343.73 & 379.46 & 431.27 & 87.54 & 51.8 \\
\hline \multicolumn{6}{|c|}{ 339-U1387B- } \\
\hline $18 \mathrm{X}$ & 156.63 & 169.87 & 169.87 & 13.24 & 0.0 \\
\hline $19 x$ & 168.22 & 181.08 & 181.27 & 13.05 & 0.1 \\
\hline $20 x$ & 176.32 & 190.58 & 190.94 & 14.62 & 0.3 \\
\hline $21 x$ & 185.51 & 202.72 & 203.89 & 18.38 & 1.1 \\
\hline $22 X$ & 196.15 & 214.00 & 218.42 & 22.27 & 4.4 \\
\hline $23 x$ & 204.785 & 223.735 & 230.10 & 25.315 & 6.3 \\
\hline $24 X$ & 216.22 & 236.35 & 245.07 & 28.85 & 8.7 \\
\hline $25 X$ & 224.16 & 247.41 & 258.14 & 33.98 & 10.7 \\
\hline $26 X$ & 233.62 & 257.02 & 271.65 & 38.03 & 14.6 \\
\hline $28 X$ & 254.91 & 278.80 & 296.09 & 41.18 & 17.2 \\
\hline $29 x$ & 263.76 & 288.77 & 308.70 & 44.94 & 19.9 \\
\hline
\end{tabular}

\begin{tabular}{|c|c|c|c|c|c|}
\hline Core & $\begin{array}{l}\text { Depth } \\
\text { (mbsf) }\end{array}$ & $\begin{array}{l}\text { Depth } \\
\text { (mcd) }\end{array}$ & $\begin{array}{l}\text { Depth } \\
\text { (c-mcd) }\end{array}$ & $\begin{array}{c}\text { Offset } \\
\text { between } \\
\text { c-mcd and mbsf } \\
(\mathrm{m})\end{array}$ & $\begin{array}{l}\text { Offset } \\
\text { between } \\
\text { c-mcd and } \\
\text { mcd (m) }\end{array}$ \\
\hline $30 x$ & 273.39 & 298.88 & 322.30 & 48.91 & 23.42 \\
\hline $31 x$ & 282.24 & 311.05 & 336.60 & 54.36 & 25.55 \\
\hline $32 x$ & 292.25 & 321.56 & 352.56 & 60.31 & 31.00 \\
\hline $33 x$ & 300.53 & 331.34 & 369.45 & 68.92 & 38.11 \\
\hline $34 X$ & 309.54 & 341.35 & 384.88 & 75.34 & 42.53 \\
\hline $35 x$ & 319.40 & 352.21 & 399.45 & 80.05 & 47.24 \\
\hline $36 x$ & 328.70 & 362.51 & 412.09 & 83.39 & 49.56 \\
\hline \multicolumn{6}{|c|}{ 339-U1387C- } \\
\hline $3 \mathrm{R}$ & 300.61 & 336.21 & 372.76 & 72.15 & 36.55 \\
\hline $5 R$ & 322.07 & 358.14 & 405.31 & 83.24 & 47.17 \\
\hline $7 R$ & 338.93 & 375.60 & 425.55 & 86.62 & 49.95 \\
\hline $8 \mathrm{R}$ & 349.24 & 386.41 & 439.16 & 89.92 & 52.75 \\
\hline
\end{tabular}

Revised splice using Core 339-U1387C-2R 339-U1387A-

$\begin{array}{lrllll}34 X & 309.54 & 341.35 & 374.45 & 64.91 & 33.10 \\ 35 X & 319.40 & 352.21 & 391.15 & 71.75 & 38.94 \\ 36 X & 328.70 & 362.51 & 403.30 & 74.60 & 40.79 \\ 37 X & 338.93 & 375.60 & 421.24 & 82.31 & 45.64 \\ 38 X & 349.24 & 386.41 & 434.95 & 85.71 & 48.54 \\ 339-U 1387 B- & & & & \\ 32 X & 293.85 & 329.05 & 360.05 & 66.20 & 31.00 \\ 33 X & 300.61 & 336.21 & 370.41 & 69.80 & 34.20 \\ 34 X & 317.12 & 349.97 & 388.59 & 71.47 & 38.62 \\ 35 X & 322.07 & 358.14 & 401.47 & 79.40 & 43.33 \\ 36 X & 335.26 & 369.79 & 415.44 & 80.18 & 45.65 \\ 339-U 1387 C- & & & & & \\ \text { 2R } & 300.35 & 331.16 & 362.16 & 61.81 & 31.00 \\ \text { 3R } & 308.30 & 340.47 & 373.11 & 64.81 & 32.64 \\ \text { 5R } & 329.44 & 363.57 & 406.83 & 77.39 & 43.26 \\ \text { 7R } & 343.73 & 379.46 & 425.50 & 81.77 & 46.04 \\ \text { 8R } & 300.61 & 336.21 & 387.80 & 87.19 & 51.59\end{array}$

All depths refer to the splice transition at the top of each core. 